\title{
The Effect of Technological Pedagogical Content Knowledge Based Training Programs Used in Astronomy Classes on the Success Levels of Science Teacher Candidates
}

\author{
Onder Sensoy ${ }^{*}$, Halil Ibrahim Yildirim \\ School of Science Education, Gazi Education Faculty, Gazi University, Turkey
}

Copyright $\subseteq 2018$ by authors, all rights reserved. Authors agree that this article remains permanently open access under the terms of the Creative Commons Attribution License 4.0 International License

\begin{abstract}
The aim of this study is to examine the impact of the Technological Pedagogical Content Knowledge (TPCK) based educational practices in astronomy lectures on prospective science teachers' success levels. The study was conducted on 4th-grade prospective science teachers of a public university and lasted for 14 weeks. In the study, quasi-experimental method and pre-test post-test control group experimental design were employed. The study was conducted in 2015-2016 Academic Year, in the Astronomy Course. In total, 72 students (control group=35, experimental group=37) participated in the study. "Astronomy Success Test" was used as data collection tool. The KR-20 reliability coefficient of the test was calculated as 0.81 . During the research process, the instruction was carried out by following the current Astronomy Course Curriculum in both groups. In addition to this, in the instruction process of the experimental group TPCK based educational practices were applied. In the research, it was determined that an improvement has occurred in success levels at a significant level of the students in the experimental group. In addition, it was also determined that the post-test astronomy success scores of the students in the experimental group are significantly higher than the scores of the students in the control group.
\end{abstract}

\footnotetext{
Keywords Technological Pedagogical Content Knowledge, Technological Pedagogical Content Knowledge Based Educational Practices, Astronomy Education, Science Education, Prospective Science Teachers
}

\section{Introduction}

As computers, software and mobile applications have penetrated into our lives in the recent years, studies on "pedagogical content knowledge" continue to be the focus of current research in the field of education and teachers' competency in using advanced technologies and training technologies (smartboard, computer, simulation software, scientific measurement tools such as probeware etc.) and applying them in teaching process have been put on the agenda. Generalizing the use of new and advanced technological training programs by teachers and their impacts on students are issues that should be researched.

Shulman (1986) analyzed the knowledge teachers must have in three categories: "content knowledge, curriculum knowledge and pedagogical content knowledge" and defined the distinctions between these categories. Pedagogical content knowledge covers what a teacher knows and does, and reasons why teachers do what they do [1]. According to Shulman (1986), pedagogical content knowledge functions as a bridge between pedagogy and content knowledge. Recently, researchers have added "technological pedagogical content knowledge" to the competencies teachers must have within the framework of concept of pedagogical content knowledge. Researchers have conceptualized pedagogical content knowledge using technology in different formats within the field of education. For example, Margerum-Lays and Marx [2] used the term "pedagogical content knowledge of training technology" whereas Slough and Connell [3] preferred "technological content knowledge" (cited by Angeli \& Valanides, [4]) and Koehler and Mishra [5] preferred "Technological Pedagogical Content Knowledge", a term that is also accepted in the literature. As defined by Mishra and Koehler [6], Technological Pedagogical Content 
Knowledge (TPCK) is a type of knowledge that advances beyond a combination of technology, pedagogy and content. An extended definition of TPCK Mishra \& Koehler, [6]; Koehler \& Mishra, [7] is as follows: "A body of knowledge about explaining concepts with the help of technology, positive use of technology for teaching content knowledge with pedagogical techniques, help of technology in solving problems experienced by the students and how students may use technology to develop new knowledge theories based on their existing knowledge or to improve their existing knowledge."

The research on the "General Competencies of the Teaching Profession" conducted by the Turkish Education Association (2009) clearly lists Technological Pedagogical Content Knowledge as one of the competencies a teacher must have to achieve success in the teaching profession. Furthermore, the International Society for Technology in Education (ISTE) standardized technological knowledge teachers and administrators in the field of education must have all around the world as "technology standards" and "performance indicators" [8]. Furthermore, these standards, which are known as the National Educational Technology Standards (NETS) in the USA, are the basis of student standards and technology standards for teachers and administrators. The National Council for Accreditation of Teacher Education (NCATE) in the USA cooperated with the ISTE to design these standards [9]. These standards and performance indicators, determined as a result of these studies, were adapted into Turkish by Saban [10].

McCrory [11] argued that the TPCK of science teachers has four elements. These are science, students, pedagogy and knowledge of technology. These four elements are combined when a teacher uses technology in the teaching process. There are two reasons for a teacher's use of technology in a classroom. These are as follows: 1 . Recognizing problems related to teaching or learning a subject in the curriculum and believing that technology can help to overcome these difficulties in learning; 2.The subject is intertwined with technology or teaching of the subject requires the use of technology. As the technology, teachers, students and class contents change, the digital technologies used in TPCK (computers and communication technologies and the internet, special purpose software programs etc.) offer a dynamic structure containing the knowledge a teacher needs to plan a teaching program and to focus on teaching students the respective subjects and prepare their ideas for teaching through digital technologies [12]. Cavin [13] added a different category into the knowledge groups teachers must have: "Knowledge of a technological tool". This is different from the personal use of that tool by the teacher. It refers to using technology as a pedagogical tool through a teaching strategy. Technology is the relation between pedagogy and content. Actually, TPCK is the extended version of Pedagogical Content Knowledge (PCK); it refers to a teacher's knowledge in combining technology and pedagogical strategies when teaching a subject related to the content and effect of technological tools and how students display their comprehension of that subject [14].

A review of studies and projects on the effective use of educational technologies reveals that big budgets are allocated for these and that great effort is expended. At the same time, although schools might have technological equipment it is teachers who will use these educational technologies and implement teaching programs [15]. TPCK refers to effective and efficient in-class use of PCK and educational technologies by teachers so that they can effectively teach by using technology as well as referring to the proper and effective integration of technology and teaching. Having teachers and teacher candidates be aware of these programs, as well as graduating from universities as individuals qualified in TPCK, and ensuring that they are comfortable with technology and have self-confidence in their fields will make the education system more productive and facilitate the process of achieving educational goals.

Scientific and technological information is an important criterion in the modernization and development of societies. Scientific and technological knowledge emerges as a product of people's sense of wonder and attempts to understand nature. Education received at early ages allows a person to be more sensitive towards their surroundings and to question their environment as well as contributing to the construction of more durable foundations for scientific and technological processes. In this regard, attempts to understand nature are of great prominence in science and technology classes. In education, one of the primary goals of the science and technology curriculum has been stated as creating science-literate individuals and this confirms the relationship between this curriculum and scientific and technological information. Today, we live in an age of technology and science and technology teachers are expected to produce individuals who are technology literate. However, the teachers can only educate technology-literate individuals if they are technology-literate themselves, and they need to combine their technological knowledge, content and pedagogical knowledge as well as using them effectively and adequately within their classroom activities [4, 28, 6, 29]. Today, it has become necessary to keep up with scientific and technological advancements in many areas. One of the most crucial of these areas is education. In this sense, we should apply information and communication technologies to the educational environment and use them in these environments within the framework of a quality education approach, while also extending the use of this approach. When we bear this fact in mind, having TPCK competencies has become an inevitable requirement for teachers. Moreover, the literature contains several research studies that have concluded that the use of technology in education improves student success [30-37]. TPCK competency has been defined by taking into consideration 
the intertwined relationship of technology and our lives in the $21 \mathrm{st}$ century, the development of teachers' competencies in using technology and the technological aspect of teacher competency explained as PCK. Improving this competency, which is a recent field of study, has been studied intensively.

According to Yildiz [78], it is important for teachers to have the TPCK qualification to successfully integrate technology into their classes. In this study, the teaching process was enriched with technological applications, so TPCK based training program was included. TPCK-based training program also includes intriguing and student-interactive technological applications that can contribute to student learning and provide student participation.

Astronomy subjects generally include abstract concepts. Therefore, it is regarded as one of the science subjects which is difficult to be understood and perceived at a conceptual level by students [43]. In order to learn the concepts of astronomy, students should envisage sizes of celestial bodies in comparison to each other, the rate of distance between them, their spatial locations and geometrical figures. However, most of the learner groups cannot actualize these [41,42]. In addition to this, studies on Astronomy, which is the subject of this study, have criticized errors in the content of teaching programs in the field, noted that there is a lack of people who can properly explain topics and addressed the importance and benefits of topics in astronomy subjects. They have also revealed the conceptual errors made by teachers, teacher candidates and students and their level of knowledge of astronomy and argued that teacher candidates, teachers and students have several misconceptions about topics related to astronomy. Furthermore, these studies argue that astronomy improves general levels of understanding and helps to broaden people's perspectives [16-19].

Properly teaching astronomy topics requires properly understanding them. Failure to understand the exact meaning of facts and concepts or to understand them clearly can alienate people from this field and turn the subject into one which is looked on unfavorably or avoided in class. It is also known that science teachers and science teacher candidates have insufficient program and material knowledge to integrate technology into the astronomy topics of the curriculum and teacher candidates have very poor knowledge about the objectives of the curriculum, concepts specific to astronomy, achievements, and the existing technologies that will be used in the education of this subject [79]. In this context, it is thought that the TPCK-based training programs, which have been developed using content that ensures that topics within Astronomy can be better understood, will contribute to a greater comprehension of these topics.

\section{Purpose of Research}

The purpose of this research is to study the effect of
Astronomy classes taught with TPCK-based Training Programs on the success levels of science teacher candidates.

\section{Method}

\subsection{Research Design}

A quasi-experimental method was used for the research. Pretest-posttest control group experimental design was used in the study [20]. The research model is quasi-experimental because existing classes were used as the control and experimental groups during the research, the students in these classes were not replaced, the principle of randomness was not used in selecting the students or the students were not assigned by lot to the experimental and control groups [21,22].

\subsection{Research Workgroup}

The study group of the research consists of 4th-grade prospective teachers who receive education in the Science Teaching Department of Faculty of Education in the academic year of 2015-2016. In the study, the convenience sampling method was used in terms of identifying the sample $[21,22]$. In terms of the selection of experimental and control groups, the branches were matched-up according to the equivalency at first. This match-up was based on the semester grade-point averages of the branches. In the match-up that was conducted in this direction, among the branches of $\mathrm{A}, \mathrm{B}$ and $\mathrm{C}$, it was determined that the branches of $\mathrm{A}$ and $\mathrm{C}$ are equivalent and involved in the study. The decision of which group should be assigned as control or assignment was made through the random assignment method. All of the prospective teachers who constitute the groups are graduated from general high schools and Anatolian high school which are public schools. In the study group that consists of 72 students, there are 35 students (26 females; 9 males) in the control group and 37 students ( 28 females; 9 males).

Table 1. Descriptive Statistical Results of Students Based on Participation in Control and Experimental Groups

\begin{tabular}{|c|c|c|}
\hline Group & N & \% \\
\hline Control & 35 & 48.6 \\
\hline Experimental & 37 & 51.4 \\
\hline Total & 72 & 100 \\
\hline
\end{tabular}

As seen from the table, control group students accounted for $48.6 \%$ of the sample and the experimental group for $51.4 \%$.

\subsection{Application of Research}

The experimental stage of the research was completed 
within a period of 14 weeks during the Astronomy classes offered two hours per week to senior science teacher candidates attending the Faculty of Education of a state university located in Turkey during the 2015-16 academic year. For the application stage of the research, the teacher candidates in the control group were not subjected to any experimental process, and the Astronomy class, which is one part of the science teacher training program offered by Faculties of Education, was taught by following the curriculum. The students in the experimental group followed the curriculum offered to the control group but the researcher used the TPCK-based Training Program about that week's topic and predetermined activities during the last 15 minutes of the weekly class. These applications were created using simulation, animation, virtual laboratory environments, augmented reality applications, mobile applications, online assessment and evaluation tools, effective presentation programs, social media tools and field-specific technological tools. The data collection tool, which was given to both groups as a pretest before starting the research, was reapplied to the groups at the end of research as a posttest.

\subsection{Data Collection Tool and Analyses}

Research data was collected by using the "Success in Astronomy Test" (success test). The 32-multiple choice question test was designed by the researcher in a format covering the course contents of the Astronomy class included in the curriculum for senior students attending the Department of Science Teaching. (In a way to comprehend the sun and the solar system, stellar, galaxies, the Big Bang, the formation of the universe, universe and space). The test designed was submitted to the experts for opinion; it was concluded that the test had content validity and the distinctiveness indices of articles, their difficulties and reliability co-efficient were calculated with a pre-application after making the necessary corrections. Two items were removed from the test because they had distinctiveness indices under 0.20 and 30 items with distinctiveness indices varying between 0.30 and 0.69 were included in the test following the necessary corrections. The success test was completed by assuring content validity. This success test's reliability co-efficient was calculated as 0.81 .

Central tendency statistics such as mode, median and mean as well as central distribution statistics such as coefficient of skewness, standard deviation and coefficient of kurtosis were used for determining the distributions of answers given by the students and examining whether the distribution of quantitative data obtained from data collection tools was normal. Before analyzing the points obtained from the data collection tools, research was undertaken into which statistical method to use for the analysis of quantitative data obtained from measurement tools and a decision was made. Parametric and nonparametric statistical methods can be used for analysis of data obtained as a result of quantitative research. If parametric statistical analysis methods are to be used in a research study, the quantitative data obtained from measurement tools must have a normal distribution [40]. Accordingly, analyses were performed to determine the statistical methods to be used for analysis of research data and the results were as follows: As seen in the data given in Table 2, the success grades of students in Astronomy were examined to determine whether their distribution was normal.

As seen in Table 2, the average scores, median and mode values of students are close to each other. Furthermore, the coefficients of kurtosis and skewness related to the scores students achieved from these scales vary between -1.5 and +1.5 . The fact that students have similar arithmetic means, median and mode values related to these scales as well as findings range of coefficients of kurtosis and skewness (range between -1.5 and +1.5 ) verify that the data has normal distribution [23-25]. It was agreed that parametric tests must be used for the analysis of data confirmed to have normal distribution based on these descriptive statistical results. Accordingly, the "T-test for Independent Groups" was performed for determining whether there was significant different between academic achievement pretest and posttest scores of students in control and experimental groups and the "T-test for Dependent Groups" was performed for comparing pretest and posttest success points of experimental and control group students in Astronomy. The results were evaluated at a significance level of .05 .

Table 2. Descriptive Statistical Results of Pretest and Posttest Scores of Students in Control and Experimental Groups

\begin{tabular}{|c|c|c|c|c|c|c|c|c|}
\hline Test & Group & $\mathbf{N}$ & $\bar{X}$ & $\mathbf{S}$ & Median & Mode & Kurtosis & Skewness \\
\hline \multirow{2}{*}{ Pretest } & Control & 35 & 13.82 & 3.27 & 12 & 12 & .752 & -.250 \\
\cline { 2 - 10 } & Experiment & 37 & 14.03 & 3.10 & 14 & 11 & .045 & -1.276 \\
\hline \multirow{2}{*}{ Posttest } & Control & 35 & 21.51 & 4.11 & 21 & 20 & .087 & -.512 \\
\cline { 2 - 9 } & Experiment & 37 & 24.78 & 3.87 & 25 & 28 & -.887 & .588 \\
\hline
\end{tabular}




\section{Findings and Comments}

In this section, data obtained from the control group that had lessons with the methods and techniques suggested by the existing curriculum and the experimental group that had Astronomy lessons taught using TPCK-based Training Programs in addition to the existing curriculum were compared and necessary analyses were carried out.

Table 3. Independent Groups T-test results of success in Astronomy Pretest Scores of Students in Experimental and Control Groups

\begin{tabular}{|c|c|c|c|c|c|c|}
\hline Group & $\mathbf{N}$ & $\overline{\mathrm{X}}$ & $\mathbf{S}$ & $\mathbf{s d}$ & $\mathbf{t}$ & $\mathbf{p}$ \\
\hline Control & 35 & 13.83 & 3.28 & \multirow{2}{*}{70} & -.265 & .792 \\
\hline Experiment & 37 & 14.03 & 3.10 & & & \\
\hline
\end{tabular}

No significant difference was observed between pre-study Astronomy success test scores of students in the experimental and control groups $\left(\mathrm{t}_{(70)}=-.265 ; \mathrm{p}>.05\right)$. According to this data, the Astronomy success scores of students attending the Astronomy class were similar before the study; $\mathrm{X}=14.03$ in the experimental group and $X=13.83$ in the control group. Accordingly, the fact that there was no significant level of difference between the Astronomy knowledge of students accords with the purpose of this study and shows that the groups were equal in this respect. The low scores of the senior class teacher candidates for such a basic level astronomy test are striking. In a study focusing on teacher candidates attending a teacher training program, Trumper [26] studied the perceptions teacher candidates had about basic astronomical concepts, and revealed that they had serious contradictions in their understanding of these concepts.

Table 4. Dependent Groups T-test Results for Success in Astronomy Posttest Scores of Students in Experimental and Control Groups

\begin{tabular}{|c|c|c|c|c|c|c|}
\hline Group & N & $\overline{\mathrm{X}}$ & $\mathbf{S}$ & Sd & t & $\mathbf{p}$ \\
\hline Control & 35 & 21.51 & 4.11 & \multirow{2}{*}{70} & \multirow{2}{*}{3.471} & .00 \\
\hline Experimental & 37 & 24.78 & 3.87 & & & \\
\hline
\end{tabular}

As seen in Table 4, there was a significant difference between the success scores of students in the experimental and control groups taking the Astronomy class after the study, and this difference was in favor of the experimental group $\left(t_{(70)}=-3,471 ; p<.05\right)$. After the experimental study, the success test average scores were calculated as $\mathrm{X}=$ 24.78 in the experimental group and $X=21.51$ in the control group. Based on the fact that there was a significant level of difference in favor of the experimental group between the success levels of the control and experimental group students in the Astronomy class, we can say that TPCK-based Training Programs had a positive impact on teacher candidates.

Table 5. Dependent Groups T-test Results for Success in Astronomy Pretest and Posttest Scores of Teacher Candidates in Control Group

\begin{tabular}{|c|c|c|c|c|c|c|}
\hline & $\mathbf{N}$ & $\overline{\mathrm{X}}$ & $\mathbf{S}$ & $\mathbf{s d}$ & $\mathbf{t}$ & $\mathbf{p}$ \\
\hline Pretest & 35 & 13.83 & 3.27 & \multirow{2}{*}{34} & -22.28 & .000 \\
\hline Posttest & 35 & 21.51 & 4.11 & & & \\
\hline
\end{tabular}

As seen in Table 5, there was a significant difference between pretest and posttest success scores of students in the control group $\left(\mathrm{t}_{(34)}=-22.28 ; \mathrm{p}<.05\right)$. Accordingly, it is concluded that the teaching methods used on the control group had positive impact on the improvement of success in the Astronomy class. It is known that science teacher candidates and teachers have an imperfect knowledge in basic topics related to astronomy and their interest in the subject is insufficient [27]. In this case, we can argue that the program was capable of overcoming these deficiencies up to a point.

Table 6. Dependent Groups T-test Results for Success in Astronomy Pretest and Posttest Scores of Teacher Candidates in Experimental Group

\begin{tabular}{|c|c|c|c|c|c|c|}
\hline & $\mathbf{N}$ & $\overline{\mathrm{X}}$ & $\mathbf{S}$ & $\mathbf{s d}$ & $\mathbf{t}$ & $\mathbf{p}$ \\
\hline Pretest & 37 & 14,03 & 3,10 & \multirow{2}{*}{36} & $-25,62$ & \multirow{2}{*}{, 000} \\
\hline Posttest & 37 & 24,78 & 3,87 & & & \\
\hline
\end{tabular}

As seen in Table 6, there was a significant difference between pretest and posttest success scores of students in the experimental group and this was in favor of the posttest results $\left(\mathrm{t}_{(36)}=-25.62 ; \mathrm{p}<.05\right)$. Accordingly, it was observed that the teaching sessions supported with TPCK-based Training Programs as well as the existing curriculum offered to the experiment group had a positive impact on the improvement of student success in the Astronomy class.

\section{Discussion and Conclusions}

It can be observed that using TPCK-based Training Programs in addition to the methods and techniques suggested by the curriculum of the Astronomy class, which is one of the senior class courses taken during science teacher training programs at Faculties of Education in Turkey, significantly increases the success levels of students in the experimental group taking Astronomy classes. When the literature is examined, it is seen that there are many lack of information and misconceptions in studies conducted with teacher and teacher candidates related to astronomy topics as a result of not understanding, concretization or misinterpretation of astronomy topics mostly composed of abstract concepts. For example, in his study, Bostan [89] found that students with different education levels between the ages of 10 and 23 had conceptual misconceptions about astronomy topics; Baloglu [80] studied 6th grade students' misconceptions about astronomy; Tunca [81] notes that some inaccuracies and deficiencies in astronomy-related courses; Unsal et al. [19] found that higher education students had lack of knowledge in basic astronomy topics. In addition to these, there are studies supporting this research's results in the literature that affect students' success in astronomy topics positively in that the technological pedagogical content knowledge based educational practices materializes the abstract concepts of astronomy. For example, Hassan 
Zadeh Baran [82] found that educational animation from technological pedagogical content knowledge based educational practices is effective at a significant level in increasing the success of the second grade students studying science teaching and the 11th grade students of the secondary school. The research conducted by Colak [83] investigated the effects of computer-assisted technological pedagogical content knowledge based educational practices on the success of science teacher candidates in the astronomy course. In the research, it was determined that the computer assisted technological pedagogical content knowledge based educational practices increased the astronomy achievements of science teacher candidates. In the work done by Sirakaya [84], it was determined that augmented reality involved in technological pedagogical content knowledge based educational practices in 7 th grade Science and Technology course, Solar System and Beyond: Space Puzzle chapter is effective in increasing the success of students and reducing the misconceptions. It can be concluded that the academic success levels of the students in the control group increased significantly during the period of education and the academic success scores of students in the experimental group were significantly higher than those of the students in the control group at the end of the study. The reason for the increase in the success of the control group students can be explained by the fact that astronomy topics are not only interesting but also that teacher candidates learn very little about astronomy topics in middle school and high school during their education life, and they don't take this course until the last semester during university education.

Although successes of both groups were at the same level at the beginning of the study, these results suggest that the use of contemporary TPCK-based Training activities in Astronomy classes is more effective in improving the success levels of science teacher candidates than the methods used in the control group. The TPCK-based Training program used in the research includes applications such as animation, simulation, augmented reality, online exams, online puzzles, virtual classroom, concept cartoons, digital story, QR code, etc. These applications have been used with the tablet PC and smart board. TPCK-based educational practices are interesting, student-interactive, and have the characteristics of being able to give feedback to students and actively used by students. In this context, the reason for the research results can be explained by the fact that the TPCK-based educational practices are interactive with the students, attract the students' interest, prosper the learning-teaching process, give feedback to students, and students can participate directly and actively in the learning process. In addition, the teachers' acknowledgement of the technological pedagogical content knowledge as a teacher competence and the need to have this ability, to see how technological pedagogical content knowledge is used in learning environments and how to use it can also have an effect on this result. There are studies in the literature that support the research result. For example, in a study conducted by Sensoy and Yildirim [85], they have examined the effects of the TPCK-based Training activities on students' academic success and reached the conclusion that these activities have a positive impact on the students' success. Sahin \& Akbaba [86] found that computer assisted use of technological pedagogical content knowledge education practices was found to be effective at the 7th grade students in learning abstract concepts within the "Solar System and Beyond, Space Puzzle" topics and in increasing academic success. Shelton and Hedley [47] investigated the impact of the augmented reality from the technological pedagogical content knowledge based educational practices on the students' success, understanding levels and conceptual misconceptions about "the World and the Sun". As a result of the study, it has been found that while the students' success level and the conceptual understanding level increases, the concept misconceptions level decrease. In the research conducted by Yildirim and Sensoy [87], the effect of the technological pedagogical content knowledge education practices such as animation, simulation, augmented reality, online exams, online puzzles, virtual classroom, concept cartoons, digital story, QR code, etc. on the success of sixth grade students in science class was investigated. As a result of the research, it has been determined that the technological pedagogical content knowledge education practices are found to be significantly effective to improve students' success level and to ensure permanence. Benli, Kayabaşı \& Sarıkaya [88] have concluded that the technological pedagogical content knowledge education practices have a meaningful effect on the success of the 7 th grade students and the permanence of this success.

In various studies conducted in the field, it has been found similarly that delivering lectures via the technological-pedagogical content knowledge-based educational practices increase the success of students [44-51]. It is thought that the advantages of using technological educational practices are effective in terms of reaching this result. One of the advantages is the increase in students' attention and interest towards the course through these practices [52-55]. Another advantage is to enable students to take an active role during the lectures and to make students ask more questions to the instructor [51, 52]. Taking an active role in lecture and asking relevant questions to the lecturing may contribute to the learning of the subjects better and profoundly. In addition, it is known that technological educational practices increase the students' motivation towards lectures [55-60].

Today, the use of fast-growing technology, as well as its products and applications, is unavoidable in the field of education. It is a known fact that computer-aided, technology-based and TPCK-based programs improve 
students' motivation and contribute to adequate and permanent learning. Prospective teachers graduate with a limited knowledge of the strategies of integrating technology into instruction [61]. Teacher candidates must be aware of these applications and use these applications in the teaching profession. According to Niess [29], TPCK refers to the use of 21 st century technologies by a teacher for planning, arranging, criticizing and summarizing a subject so that the teacher can support the learning process of students by taking into their needs and in-class conditions.

Due to the fact that science courses include various abstract concepts, visualizing via technology can be preferred because of its features as being economic, easily accessible, safe, and repeatable [62]. Furthermore, simulations in science teaching enable students to learn by playing, in other words by enjoying,; and this play an important role in terms of "psychological, intellectual and social development" of a child and as they enjoy while learning their motivation also increase and this leads to an effective learner experience [63]. Science teachers' TPFKs can be improved through applications that provide real-like experiences, by gaining authentic learning experiences, instructing in classroom and feedback corrections [64].

Astronomy enables students to understand the world more effectively. An anatomist must have anatomical knowledge to have a better understanding of human body and in a similar way, humans need a knowledge of astronomy in order to understand the universe. In addition, an education in astronomy can be used to overcome any misconceptions students have. Learning astronomy can be considered a factor in changing students' conceptual understanding [38]. Astronomy is a field that is difficult to understand and that requires advanced skills such as three-dimensional thinking and the use of the imagination. Hence, insufficient knowledge of astronomy among teachers or candidate teachers or the wrong information they have might cause them to pass on misconceptions that cannot be easily corrected to their students and the students might tend to accept the non-scientific ideas offered by society without even questioning them. Here, one of the necessary actions to be taken for preventing the abovementioned problems is to refreshing the basic astronomical knowledge of teachers by using technology training programs in tandem with today's technology. It is almost impossible for students to learn about astronomical incidents by observing or intervening and observing the result. Therefore, tools that will help students to learn about astronomy subjects are required. Technological-pedagogical content knowledge-based practices such as increased virtual reality are considered as effective tools in terms of students' learning of astronomy subjects which include complex spatial relations. When the literature is reviewed, it can be seen that students can be enabled to directly observe in order to support their learning related to astronomy subjects [65, $66,48,67,68,69,70,51]$ so they can interact with celestial bodies $[42,71,45,72,47,73]$. It is seen that Technological-Pedagogical Content Knowledge-Based Practices have been improved. It is known that these practices facilitate the comprehension of difficult subjects and concepts by visualizing $[74,65,47]$.

If the instructors who raise prospective teachers use technology regularly while they are teaching science and clearly indicate why and how they use technology, prospective teachers take it as an example and employ technology in their instructions [75]. In this way, prospective teachers learn how to teach via technology. As Niess (2008) indicates "Teachers teach what they had taught to them". For this reason, prospective teachers' experiences related to learning via technology also affect their instructions. Prospective teachers who have the experience of visual learning tend to apply these experiences to their instructions [77].

It is thus appropriate to explicitly highlight TPCK under the teacher competencies related to general and specific fields and to evaluate TPCK levels of teachers. "Technology standards" and "performance indicators" must be designed for teachers as well as teacher candidates, students and training directors [39]. Furthermore, in parallel to the knowledge gained at university, teacher candidates should be provided with an opportunity to have teaching experience in real classrooms where they can use TPCK-based Training Programs and courses involving such subjects should include up-to-date TPCK applications and the use of effective technology.

\section{REFERENCES}

[1] Baxter, J. A. \& Lederman, N. G. Assessment and Measurement of Pedagogical Content Knowledge. In J. Gess-Newsome \& N. G. Lederman (Eds.), Examining pedagogical content knowledge (pp. 147-161). Dordrecht: Kluwer, 2009

[2] Margerium-Lays \& Marx, R.W. Teacher knowledge of education tecnology: A case study of student/mentor teacher pairs. In Y. Zhao (Ed.). What should teachers know about technology? Perspectives and practices (pp. 123-159). Greenwich, CO: Information Age, 2003

[3] Slough, S. \& Connell, M. Defining tecnology and its natural corollary, technological content knowledge (TCK). In C. Crawford et al. (Eds.), Proceedings of Society for Information Technology and Teacher Education International Conference 2006 (pp. 1053-1059). Chesapeake, VA; AACE, 2006.

[4] Angeli, C. \& Valanides, N. Epistemological and methodological issues for the conceptualization, development, and assessment of ICT-TPCK: Advances in technological pedagogical content knowledge (TPCK). Computers \& Education, 52, 154-168, 2009. 
[5] Koehler, M. J. \& Mishra, P. What happens when teachers design educational technology? The development of technological pedagogical content knowledge. Journal of Educational Computıng Research, 32(2), 131-152, 2005.

[6] Mishra, P. \& Koehler, M. J. Technological pedagogical content knowledge: A framework for integrating technology in teacher knowledge. Teachers College Record, 108(6), 1017-1054, 2006.

[7] Koehler, M. J. \& Mishra, P. What is technological pedagogical content knowledge? Contemporary Issues in Technology and Teacher Education, 9(1),60-70, 2009.

[8] International Society for Technology in Education - ISTE. ISTE National Educational Technology Standards (NETS) and Performance Indicators for Teachers. Web: http://www.iste.org/AM/Template.cfm?Section=NETS. 2000 .

[9] Resta,P. Ogretmen egitiminde bilgi ve iletisim teknolojileri: Planlama rehberi. (Cev. H.F. Odabası) Ankara: Nobel Yayin Dagitim. 2000.

[10] Saban, A. Okul teknoloji planlamasi: ilkogretim okullari icin uygulamali bir model onerisi ve ogretmen yetistirme sistemi acisindan sonuclari. Yayinlanmamis doktora tezi. Selcuk Universitesi, Sosyal Bilimler Enstitusu, Konya. 2000.

[11] McCrory, R. Science, Technology, and Teaching The Topic-Specific Challenges of TPCK in Science, In. AACTE Committee on Innovation and Technology, Handbook of Technological Pedagogical Content Knowledge (TPCK) For Teaching and Teacher Educators (pp. 193-206). Routledge: New York and London. 2008.

[12] Niess, M. L., Ronau, R. N., Shafer, K. G., Driskell, S. O., Harper S. R., Johnston, C., Browning, C., Ozgun-Koca, S. A. \& Kersaint, G. Mathematics teacher TPACK standards and development model. Contemporary Issues in Technology and Teacher Education, 9(1), 4-24. 2009.

[13] Cavin, R. M. Developing Technological Pedagogical Content Knowledge in preservice teachers through microteaching lesson study. PhD Thesis, the Florida State University Shulman, L. (1986). Those who understand: Knowledge growth in teaching. Educational Researcher, 15(2), 4-14, 2007.

[14] Graham, C. R., Burgoyne, N., Cantrell, P., Smith, L., St. Clair, L., \& Harris, R. TPACK Development in Science Teaching: Measuring the TPACK Confidence of Inservice Science Teachers, TechTrends, Special Issue on TPACK, 53(5), 70-79, 2009.

[15] Turk Egitim Dernegi. Ogretmen Yeterlikleri, Ankara: Adim Okan Matbaacilik. 2009.

[16] Kececi, T. Ilkogretim ogrencilerinin astronomiyle ilgili temel kavramlari anlama duzeyi ve astronomi dersinin egitim icin onemi. 3. Uluslararasi Egitimde Yeni Yaklasimlar ve Etkileri Konferansi, Antalya. 2012.

[17] Emrahoglu, N. ve Ozturk, A. Fen bilgisi ogretmen adaylarinin astronomi kavramlarini anlama seviyelerinin ve kavram yanilgilarinin incelenmesi uzerine boylamsal bir arastirma. Cukurova Universitesi Sosyal Bilimler Enstitusu Dergisi, (18)1, 165-180, 2009.

[18] Kocer, D. Turkiye'de astronomi egitim-ogretiminin onemi, gerekliligi ve yapilabilecekler. V. Ulusal Fen Bilimleri ve Matematik Egitimi Kongresinde sunuldu, Ankara. 2002.

[19] Unsal, Y., Gunes, B. ve Ergin, I. Yuksekogretim ogrencilerinin temel astronomi konularindaki bilgi duzeylerinin tespitine yonelik bir arastirma. Gazi Egitim Fakultesi Dergisi, 21(3), 47-60, 2001.

[20] Linn RL, Gronlund NE. Measurement and assessment in teaching. 8th edn, Prentice Hall International, NJ, 2000.

[21] Buyukozturk, S., Kilic Cakmak E., Akgun, O. E., Karadeniz, S. ve Demirel, F. Bilimsel arastırma yontemleri (20. baski). Ankara: Pegem A. 2016.

[22] Karasar. N. Bilimsel arastirma yontemi (30. Baski). Nobel Yayin Dagitim. 2016.

[23] Kalayci, S. Spss uygulamali cok degiskenli istatistik teknikleri. (3. baski). Ankara: Asil Yayın Dagitim. 2008.

[24] Koklu, N., Buyukozturk, S. ve Cokluk Bokeoglu, O. Sosyal Bilimler Icin Istatistik. Ankara: Pegem A. 2006.

[25] Tabachnick, B. G. \& Fidell, L. S. Using multivariate statistics. (6th edition). Boston: Pearson. 2013.

[26] Trumper, R. Teaching future teachers basic astronomy concepts-seasonal changes-at a time of reform in science education. Journal of Research of Science Teaching, 43(9), 879-906, 2006.

[27] Tascan, M. Determine of science teachers knowledge level about basic astronomy subjects (The example of Malatya) Yayinlanmamis Yuksek lisans tezi, Inonu Universitesi, Egitim Bilimleri Enstitusu. 2000.

[28] Koehler, M., \& Mishra, P. Introducing TPCK. In AACTE Committee on Innovation and Technology (Eds.), The handbook of technological pedagogical content knowledge for teaching and teacher educators (pp. 3-29). Mahwah, NJ: Lawrence Erlbaum Associates, Publishers. 2008.

[29] Niess, M. L. Guiding pre-service teachers in developing TPCK, In. AACTE Committee on Innovation and Technology (Eds.), Handbook of Technological Pedagogical Content Knowledge (TPCK) For Educators (pp. 3-29). New York and London: Routledge. 2008.

[30] Pektas, M., Turkmen, L. \& Solak, K. Bilgisayar destekli ogretimin fen bilgisi ogretmen adaylarinin sindirim sistemi ve bosaltim sistemi konularini ogrenmeleri uzerine etkisi. Kastamonu Egitim Dergisi, 14(2), 465-472, 2008.

[31] Tuysuz, C. The effect of the virtual laboratory on students' achievement and attitude in chemistry. International Online Journal of Educational Sciences, 2 (1), 37-53, 2010.

[32] H. Tezcan, U. Yilmaz. Kimya ogretiminde kavramsal bilgisayar animasyonlari ile geleneksel anlatim yonteminin basariya etkileri Pamukkale Universitesi Egitim Fakultesi Dergisi, 2 (14) , pp. 18-32, 2003.

[33] Bakac, M. Kartal, A. \& Akbay, T. Fen ve Fizik Etkinliklerinde Bilgisayar Destekli Simulasyon Tekniginin Ogrenci Basarisina Etkisi: Elektrik Akimi Ornegi. IX. Ulusal Fen Bilimleri ve Matematik Egitimi Kongresi Ozet Kitapcigi, 91, 2010.

[34] Bozkurt and Sarikoc, Fizik Egitiminde Sanal Laboratuar, Gercek Laboratuarin Yerini Tutabilir mi? Selcuk 
Universitesi Ahmet Kelesoglu Egitim Fakultesi Dergisi, 25 (2008), pp. 89-100, 2008.

[35] Gonen, S., Kocakaya, S. \& Inan, C. The effect of the computer assisted teaching and 7E model of the constructivist learning methods on the achievements and attitudes of high school students. The Turkish Online Journal of Educational Technology - TOJET, 5(4), ISSN: 1303-6521, 2006.

[36] Wainwright, C. L. The effectiveness of a computer-assisted instruciton package in high school chemistry. Journal of Research in Science Teaching, 26(4), 275-290, 1989.

[37] Tas, E., Kose, S. \& Cepni, S. Bilgisayar destekli ogretim materyalinin fotosentez konusunu anlamaya etkisi, International Journal of Environmental and Science Education, 1(2), 163- 171, 2006.

[38] Trumper, R. The need for change in elementary school teacher training-a cross-college age study of future teachers' conceptions of basic astronomy concepts. Teaching and Teacher Education, 19, 309-323, 2003.

[39] Bilici.C. S. Fen bilgisi ogretmen adaylarinin teknolojik pedagojik alan bilgisi ve ozyeterlikleri. Yayinlanmamis Doktora tezi, Gazi universitesi, Egitim Bilimleri Enstitusu. 2012.

[40] Sim, J. \& Wright, C. Research in health care: Concepts, designs and methods. United Kingdom, Cheltenham: Nelson Thornes Ltd. 2002.

[41] Cai, S., Wang, X., \& Chiang, F.-K. A case study of augmented reality simulation system application in a chemistry course. Computers in Human Behavior, 37, 31-40, 2014.

[42] Fleck, S., Hachet, M., \& Bastien, C. Marker-based augmented reality: Instructional-design to improve children interactions with astronomical concepts. Interaction Design and Children'da sunulmus bildiri, Tufts University, Boston. 2015.

[43] Turk, C., Alemdar, M., \& Kalkan, H. Ilkogretim ogrencilerinin mevsimler konusunu kavrama duzeylerinin saptanmasi. Dunyada'daki Egitim ve Ogretim Calismalari Dergisi, 2(1), 62-67. 2012.

[44] Abdusselam, M. S., \& Karal, H. Fizik ogretiminde artirilmis gerceklik ortamlarinin ogrenci akademik basarisi uzerine etkisi: 11. sinif manyetizma konusu ornegi. Egitim ve Ogretim Arastirmalari Dergisi, 1(4), 170-181. 2012.

[45] Fleck, S., \& Simon, G. An augmented reality environment for astronomy learning in elementary grades: an exploratory study. 25. Conference Francophone Sur Interaction Homme-Machine, Bordeaux, France. 2013.

[46] Ozarslan, Y. Genisletilmis gerceklik ile zenginlestirilmis ogrenme materyallerinin ogrenen basarisi ve memnuniyeti uzerindeki etkisi. Doktora Tezi, Anadolu Universitesi Sosyal Bilimler Enstitusu, Eskisehir. 2013.

[47] Shelton, B. E., \& Hedley, N. R. Using augmented reality for teaching earth-sun relationships to undergraduate geography students. Augmented Reality Toolkit, The First IEEE International, Darmstadt, Germany. 2002.

[48] Sin, A. K., \& Badioze-Zaman, H. Live Solar System (LSS): Evaluation of an Augmented Reality book-based educational tool. 2010 International Symposium on Information Technology, Kuala Lumpu Convention Center, Malaysia. 2010.

[49] Vilkoniene, M. Influence of augmented reality technology upon pupils' knowledge about human digestive system: The results of the experiment. Online Submission, 6(1), 36-43. 2009.

[50] Yen, J.-C., Tsai, C.-H., \& Wu, M. Augmented reality in the higher education: students' science concept learning and academic achievement in astronomy. Procedia - Social and Behavioral Sciences, 103, 165-173. 2013.

[51] Zhang, J., Sung, Y.-T., Hou, H.-T., \& Chang, K.-E. The development and evaluation of an augmented reality-based armillary sphere for astronomical observation instruction. Computers \& Education, 73, 178-188. 2014.

[52] Delello, J. A. Insights from pre-service teachers using science-based augmented reality. Journal of Computers in Education, 1(4), 295-311. 2014.

[53] Gun, E. (2014). Artirilmis gerceklik uygulamalarinin ogrencilerin uzamsal yeteneklerine etkisi. Yuksek Lisans Tezi, Gazi Universitesi Egitim Bilimleri Enstisusu, Ankara. 2014.

[54] Ibili, E. Geometri dersi icin artirilmis gerceklik materyallerinin gelistirilmesi, uygulanmasi ve etkisinin degerlendirilmesi. Doktora Tezi, Gazi Universitesi Egitim Bilimleri Enstitusu, Ankara. 2013.

[55] Yen, J. C., Tsai, C. H., \& Wang, J. Y. The effects of augmented reality on students' moon phases concept learning and their conceptual changes of misconception. International Conference on Business and Information. Sapporo, Japan. 2012.

[56] Ibili, E., \& Sahin, S. Artirilmis gerceklik ile interaktif 3d geometri kitabi yazilimin tasarimi ve gelistirilmesi: ARGE3D. Afyon Kocatepe Universitesi Fen ve Muhendislik Bilimleri Dergisi, 13, 1-8. 2013.

[57] Kucuk, S., Yilmaz, R., \& Yuksel, G. Ingilizce ogreniminde artirilmis gerceklik: Ogrencilerin basari, tutum ve bilissel yuk duzeyleri. Egitim ve Bilim Dergisi, 39(176), 393-404. 2014.

[58] Matcha, W., \& Rambli, D. R. A. Exploratory study on collaborative interaction through the use of augmented reality in science learning. Procedia Computer Science, 25, 144-153. 2013

[59] Perez-Lopez, D., \& Contero, M. Delivering educational multimedia contents through an augmented reality application: a case study on its impact on knowledge acquisition and retention. Turkish Online Journal of Educational Technology - TOJET, 12(4), 19-28. 11 Ocak 2015 tarihinde http://eric.ed.gov/?id=EJ1018026 2013.

[60] Taskiran, A., Koral, E., \& Bozkurt, A. Artirilmis gerceklik uygulamasinin yabanci dil egitiminde kullanilmasi. Akademik Bilisim 15'de sunulmus bildiri, Anadolu Universitesi, Eskisehir. 2015.

[61] Suharwoto, G. Secondary mathematics preservice teachers' development of technology pedagogical content knowledge in subject-specific, technology-integrated teacher preparation program. Phd thesis, Oregon State University. 2006. 
[62] McCrory, R. Science, technology, and teaching the topic-specific challenges of TPCK in science, In. AACTE Committee on Innovation and Technology (Eds.), Handbook of Technological Pedagogical Content Knowledge (TPCK) For Teaching and Teacher Educators (pp. 193-206). New York and London: Routledge. 2008.

[63] Giovannini, M. L., Hunya, M., Lakkala, M., Moebius, S., Raymond, C., Simonnot, B. \& Traina, I. Fostering the use of ICT in pedagogical practices in science education, e-learning papers, Web:

http://www.elearningeuropa.info/files/media/media23119. pdf. 2010 .

[64] Jimoyiannis, A. Developing a technological pedagogical content knowledge framework for science education: implications of a teacher trainers' preparation program. Proceedings of Informing Science \& IT Education Conference (InSITE), Web:

http://proceedings.informingscience.org/InSITE2010/InSI TE10p597-607Jimoyiannis867.pdf. 2010.

[65] Kerawalla, L., Luckin, R., Seljeflot, S., \& Woolard, A. Making it real: Exploring the potential of augmented reality for teaching primary school science. Virtual Reality, 10(3-4), 163-174. 2006.

[66] Sin, A. K., \& Badioze-Zaman, H. Tangible interaction in learning astronomy through augmented reality book-based educational tool. Lecture Notes in Computer Science, 5857, 302-313. 2009.

[67] Soga, M., Matsui, K., Takaseki, K., \& Tokoi, K. Interactive learning environment for astronomy with finger pointing and augmented reality. Eighth IEEE International Conference on Advanced Learning Technologies'de sunulmus bildiri, Santander, Cantabria. 11 Haziran 2015 tarihinde http://doi.org/10.1109/ICALT.2008.144. 2008.

[68] Tian, K., Endo, M., Urata, M., Mouri, K., \& Yasuda, T. Multi-viewpoint smartphone ar-based learning system for astronomical observation. International Journal of Computer Theory and Engineering, 6(5), 396-400. 2014.

[69] Tian, K., Endo, M., Urata, M., Mouri, K., \& Yasuda, T. Ubiquitous augmented reality mobile learnıng system for supportıng moon observation. The International Conference on Business and Information'da sunulmus bildiri, Bali, Indonesia. 27 Aralık 2014 tarihinde http://ibac-conference.org/ISS\%20\&\%20MLB\%202013/P apers/ISS\%202013/A3260..pdf. 2013.

[70] Yen, J.-C., Tsai, C.-H., \& Wu, M. Augmented reality in the higher education: students' science concept learning and academic achievement in astronomy. Procedia - Social and Behavioral Sciences, 103, 165-173. 2013.

[71] Fleck, S., Simon, G., \& Christian Bastien, J. M. Aible: An inquiry-based augmented reality environment for teaching astronomical phenomena. 2014 IEEE International Symposium on Mixed and Augmented Reality - Media, Art, Social Science, Humanities and Design'da sunulmus bildiri, Munich, Germany. 2014.

[72] Medicherla, P. S., Chang, G., \& Morreale, P. Visualization for increased understanding and learning using augmented reality. International Conference on Multimedia Information Retrieval'da sunulmus bildiri, New York, NY, USA. 2010.
[73] Shelton, B. E., \& Stevens, R. Using coordination classes to interpret conceptual change in astronomical thinking. 6th International Conference for the Learning Sciences'da sunulmus bildiri, Santa Monica, California. 2004.

[74] Bujak, K. R., Radu, I., Catrambone, R., MacIntyre, B., Zheng, R., \& Golubski, G. A psychological perspective on augmented reality in the mathematics classroom. Computers \& Education, 68, 536-544. 2013.

[75] McCrory, R. Science, technology, and teaching the topic-specific challenges of TPCK in science, In. AACTE Committee on Innovation and Technology (Eds.), Handbook of Technological Pedagogical Content Knowledge (TPCK) For Teaching and Teacher Educators (pp. 193-206). New York and London: Routledge. 2008.

[76] Niess, M. L. Guiding pre-service teachers in developing TPCK, In. AACTE Committee on Innovation and Technology (Eds.), Handbook Of Technological Pedagogical Content Knowledge (TPCK) For Educators (pp. 3-29). New York and London: Routledge. 2008.

[77] Moreno, R. Abercrombie, S. \& Hushman, C. Using virtual classroom cases as thinking tools in teacher education, In. C.D. Maddux (Eds.), Research Highlights in Technology and Teacher Education, SITE, 231-238. 2009.

[78] Yildiz, H. Analysis of Development of Technological Pedagogical Content Knowledge on Geometry of Mathematics Teachers, Unpublished Doctoral Dissertation, Karadeniz Teknik Universitesi Egitim Bilimleri Enstitusu, Trabzon. 2017

[79] Kilic, A. \& Kazanc, S. Pre-Service Science Teachers' Technological Pedagogical Content Knowledge Involving the Topic of the Lunar and Solar Eclipses. Turkish Journal of Education Studies. 3 (3). 2016

[80] Baloglu, N. U. Ilkogretim 6. sinif ogrencilerinin Dunya ve Evren konusu ile ilgili kavram yanilgilari. Gazi Egitim Fakultesi Dergisi, 25(1), 229-246. 2005

[81] Tunca, Z. Turkiye'de ilk ve orta ogretimde astronomi egitim ogretiminin dunu, bugunu. V. Ulusal Fen Bilimleri ve Matematik Egitimi Kongresinde sunuldu, Ankara. 2002

[82] Hassan Zadeh Baranı, G. Bilgisayar destekli animasyonla ogretim yonteminin fen bilgisi ogretmenligi fizik 4 (modern fizik) dersi ile ortaogretim 11. sinif modern fizik dersindeki akademik başariya etkisi. Yayinlanmamiş Yuksek Lisans Tezi, Cukurova Universitesi Sosyal Bilimler Enstitüsü, Adana. 2014

[83] Colak, O. Astronomi Dersinin Ogretiminde Bilgisayar Destekli Egitim Yonteminin Ogrenci Basarisina Etkisi. Yayinlanmamis Yuksek Lisans Tezi, Firat Universitesi Egitim Bilimler Enstitusu, Elazıg. 2014

[84] Sirakaya, M. Artirilmiş gerçeklik uygulamalarinin öğrencilerin akademik başarilari, kavram yanilgilari ve derse katilimlarina etkisi. Yayinlanmamis Doktora tezi, Gazi universitesi, Egitim Bilimleri Enstitusu. 2015.

[85] Sensoy, O. \& Yildirim, H.I. Bilisim teknolojileri ve uygulamalari ile islenen fen derslerinin ogrencilerin akademik basari duzeyleri üzerine etkisi. International Association of Educational Researchers (ULEAD). Canakkale. 2017 
[86] Sahin, R. \& Akbaba, U. (2018). Bilgisayar Destekli Ögretimin "Gunes Sistemi ve Otesi, Uzay Bilmecesi" Unitesindeki Ogrenci Basarisina ve Derse Karsi Ogrenci Tutumuna Etkisi. E-Kafkas Egitim Araştirmalari Dergisi, 5(1), 10-24.

[87] Yildirim, H.I. \& Sensoy, O. Effect of Science Teaching Supported By Technological Practices on the Achievements of 7th Grade Students. 20 - 23 April 2017, 26th International Conference on Educational Sciences (ICES/UEBK-2017), Antalya. 2017
[88] Benli, E., Kayabasi, Y. \& Sarikaya M. The Effect of Supported Science Education to the Science Achievement, the Permanence of Knowledge and the Attitudes toward Science of 7th Grade Students, Gazi University Journal of Gazi Educational Faculty, Vol.32, No.3, 733-760, 2012.

[89] Bostan, A. Farkli yas grubu ogrencilerin astronominin bazi temel kavramlarina iliskin dusunceleri. Yayimlanmamis Yuksek Lisans Tezi, Balikesir Universitesi Fen Bilimleri Enstitusu, Balikesir. 2008. 